\title{
After the Arab Spring: an opportunity for scenarios
}

\author{
P. W. F. Van Notten
}

Received: 29 July 2013 / Accepted: 17 October 2013 /Published online: 21 November 2013

(C) The Author(s) 2013. This article is published with open access at Springerlink.com

\begin{abstract}
Since the start of the Arab Spring, the Middle East has been the scene of conflict that resonates far beyond its borders. This paper will argue that the upheavals in the Middle East cry out for a long view and that scenario development in theory is well positioned to give it and has an interest in doing so. However, the paper will also suggest that scenario methodology for informing policy decisions for the contemporary Middle East is underdeveloped. The paper will outline some of the methodological challenges. It will also suggest improvements and alternative uses for scenarios for the Arab Spring Middle East.
\end{abstract}

Keywords Arab Spring · Middle East · Scenario development $\cdot$ Discontinuity

\section{Introduction}

On December 17th, 2010, an exasperated Mohammed Bouazizi set himself alight in an ultimate act of protest after a brush with local authorities. In death, the Tunisian street vendor thumbed his nose at those authoritarian officials who he felt belittled by over the years. His defiant act triggered a wave of protest so large that it unseated long time Tunisian president Zine El Abidine Ben Ali within a month. The knockon effect across the region was both large and unforeseen.

Bouazizi's self-immolation was an unlikely trigger of regional upheaval. Yet 2,5 years after his act sparked the Arab Spring, the Middle East especially is the scene of conflict that resonates far beyond its borders, including Europe. Coming on top of existent tensions, the upheavals have forced the hand of leaders of various stripes in uncomfortable directions. And

P. W. F. Van Notten $(\bowtie)$

Fairsights, Veemarktkade 8, 5222 AE Den Bosch, The Netherlands

e-mail: philip@fairsights.com while opinions differ widely and loudly over visions of the future and the steps needed to achieve them, they are perhaps united in their uncertainty over the outcome of the upheavals.

This paper first argues that, more than before the Arab Spring, the disruptions in the Middle East cry out for a long view. Second, it explains that the upheavals provide an opportunity for scenario development to prove its worth by providing outlooks that inform Western policy decisions. The third section, however, argues that scenario methodology is inadequate for informing decision making on the contemporary Middle Eastern upheavals. The paper will outline some of the methodological challenges. It will also suggest improvements and alternative uses for scenarios for the Arab Spring Middle East.

\section{Why the Arab Spring Middle East matters}

To argue that Middle Eastern developments resonate in the West is to state the obvious. The extension of Islam and muslim migration to Europe are commonplace examples of Middle Eastern influence elsewhere. Similarly obvious is the large Western stake in the region as exemplified by the United States' unwavering commitment to Israel. It is beyond the scope of this paper to explore the historic relationship between the West and the Middle East sufficiently to do it justice. However, it is worth noting aspects of recent history in order to explore Western interest in the region today.

The interests of Western and some Middle Eastern powers converged with the 1991 Gulf War, when a broad political and military coalition was formed to protect oil interests in Kuwait and Saudi Arabia, although the rhetoric at the time trumpeted a mainly ideological and humanitarian cause. A dynamic mix of related and sometimes conflicting interests continues to the present. To illustrate, the Western, Christian presence on Saudi Arabia's holy Islamic soil during the Gulf War stoked anti- 
Western sentiment in the region. The West's strong political and military support of such secular authoritarian regimes as those in Egypt, Jordan and Saudi Arabia was in part an effort to contain the resulting security threat. However, these relationships became difficult to reconcile with Western democratic ideals in the face of Arab Spring popular uprisings against such regimes, the Egyptian revolution being the starkest example. In short, Western involvement in the Middle East over the past decades is anchored in economic interest from which security, political, ideological and humanitarian interests derive.

The Arab Spring comes on top of such pre-existent Western concerns as the intractable Israeli-Palestinian conflict, the vulnerable post-Iraq war recovery and the brinkmanship over the Iranian nuclear development programme. Although the West is not new to explosive situations in the Middle East it struggles to respond more now than before. Why? Analysis of international news media points to five distinctive features of the Arab Spring Middle East that combine to form a more dangerous and uncertain mix than previously. These features are the security threats, the role of new media, the humanitarian disaster, the interconnection of the tensions and the speed of developments on the ground.

\section{The security threats}

Perhaps most distinctive of Western concerns over the Arab Spring Middle East is the heightened security threat resulting from increased regional instability. To date, three Middle Eastern regimes have been been toppled (Yemen and two in Egypt) and two others have seen popular uprisings against them (Syria and Bahrain). Nearly all other Middle Eastern countries' rulers have scrambled to avert similar challenges to their authority; from the arrest of bloggers in the UAE to the co-option of potential troublemakers in Jordan. However, with the Syrian conflict spilling over into neighbouring countries, further regional instability is conceivable.

Of the resulting security concerns those over Syria are arguably the most acute. Firstly, the conflict is a jihadi rallying point, radicalising individuals both inside and outside the region, including Europe, and luring some to actively take part in the fighting. Of particular concern is the threat of jihadis in Syria eventually turning their sights to the West. Secondly, there is the danger of the large stock of Assad's chemical weapons falling into the hands of the West's enemies.

Another concern is the sectarian nature of conflicts. The protests in Bahrain pitted a Sunni ruling minority against a Shia majority. The Syrian conflict is also strongly sectarian, with Iran and Hezbollah coming to the aid of a minority Shia regime while Qatar and Saudi Arabia strongly back the Sunni opposition. Furthermore, sectarian violence in Iraq has shot up in 2013 after a gradual decline in recent years. Both Syria and
Iraq are theatres for Shia Iran's efforts to assert itself against Sunni enemies. The Sunni-Shia schism is destabilising the region and it resonates beyond the Middle East, including in Europe [1].

The ascent of political Islam is also of concern to many, both in and outside the Middle East. Islamists are generally mistrustful of the West and some openly hostile to it. Commercial, diplomatic and other relationships might become complicated as a result; the future of the Israeli-Egyptian peace treaty being of a particular concern.

The role of new media

Relatively new factors and strongly influential to the Arab Spring are such new media as twitter, YouTube and satellite television. The catalytic influence of such new media as twitter and YouTube have made Western response more challenging.

The power of new media was perhaps first felt in the region during the 2009 protests in Iran following the controversial reelection of president Ahmadinejad. The footage of a dying Neda Agha-Soltan, a young protester shot during a demonstration, went viral on the web and television screens globally and served as a rallying point for further protest.

The power of new media during the Arab Spring became clear with the Egyptian revolution where social media helped both to mobilise protest in Cairo streets and to respond to it. Furthermore, Al Jazeera's near breathless coverage of the Egyptian protests carried the voice of many who previously had none to living rooms and political centres all over the world. New media has since become a weapon whose effective use influences not only events on the ground but also political agendas. At the June 2013 G8-summit, for example, Russian president Putin scored points against Western rivals who support the opposition with a reference to YouTube footage of an Islamist fighter, Abu Sakkar, biting the heart of a dead soldier.

The new media's influence is arguably strongest in putting a human face on the Arab Spring. News channels' near daily images of such places as Tahrir Square and Zataari refugee camp bring the upheavals to life in an unprecedented manner. Images of such atrocities as those in Syrian towns of Hula and Banias brought outrage, forcing governments to address the conflict where they might otherwise prefer to look away. Unfortunately, the new media have no shortage of material, given the unprecedented magnitude of the humanitarian plight.

The humanitarian disaster

The Arab Spring's human toll, particularly in Syria, is perhaps the strongest illustration of the scale of the upheaval. The official UN death toll in the Syrian conflict presently stands 
at over 100,000 . The number is less than the 120,000 in Iraq since the US-led invasion in 2003 [2], but the Syrian deaths occurred in just over 2 years time. With no end to the fighting in sight, it is reasonable to assume that the final death toll will be considerably higher.

Furthermore, of the more than 45.2 million displaced persons worldwide at the end of 2012, nearly 6.5 million were located in North Africa and the Middle East [3]. On July 16th, 2013, the United Nations announced that the Syrian conflict has caused the world's worst refugee crisis for 20 years [4]. It stated that 5,000 Syrians are killed each month and that 6.8 million people need urgent help. The UN has 1.8 million registered Syrian refugees of which two thirds have fled the country in 2013 at an average rate of 6,000 people every day. The sheer numbers have a destabilising effect on neighbouring Jordan and Lebanon, who already host large communities of Iraqi (Jordan) and Palestinian refugees. Turkey, the bridge to Europe, hosts around 400000 Syrian refugees.

\section{The interconnection of the problem}

Tensions of all sorts converge in Arab Spring Middle East: Sunni versus Shia, religion versus secularism, autocracy versus democracy, progressive versus conservative, East versus West. These combine to form an intricate mesh of dynamic forces and allegiances. A letter to the editor of a Gulf states newspaper provides an apt illustration of the complex nature of the interconnections [5].

Sir, Iran is backing Assad. Gulf states are against Assad! Assad is against Muslim Brotherhood. Muslim Brotherhood and Obama are against General Sisi head of the Egyptian military]. But Gulf states are pro-Sisi! Which means that they are against Muslim Brotherhood! Iran is pro-Hamas, but Hamas is against the US! Gulf States are pro-US. But Turkey is with Gulf states against Assad; yet Turkey is pro-Muslim Brotherhood against General Sisi. And General Sisi is being backed by the Gulf States! Welcome to the Middle East and have a nice day.

The letter describes the interconnection on a state actor level. There are many other patchworks of influential factors; from youth unemployment to tribal allegiance, water resources to Islamic schools of law. Developments in one area might have any number of knock-on effects in others. Moreover, Bouazizi's self-immolation shows that a spark in one corner of the region can have a multiplier effect, igniting a cascade of disruptions in other parts of the Middle East. Breaking issues down into manageable parts risks an oversimplification of the problem. The Middle Eastern mesh of interconnecting forces is difficult to fathom at the best of times. It is nearly impossible with the disruptions of the Arab Spring.

The speed of developments on the ground

A last factor particular to the Arab Spring upheavals is the pace at which they occur. In 2,5 years time large parts of the Middle East have seen upheaval. New media are accelerators of the change. They gather news on the ground and send it faster and further than before, inviting quicker response. The mechanism applies in various contexts; from skirmishes in Cairo streets to diplomatic negotiations in the UN Security Council. The pace is difficult to keep up with, let alone to stay ahead of, for decision-makers in Western capitals. And it allows little room for thorough analysis before taking decisions. Illustrative is Obama's unsure and hesitant response to the Egyptian revolution and the Syrian conflict.

\section{An opportunity for scenario development}

With such a multi-faceted situation crying out for a resolution, is there a role for scenario development for informing policy on the Arab Spring Middle East?

This paper works from the premise that futures research aims to explain complex problems in order to explore their possible development and inform relevant policy. Such complex problems are sometimes described as "messy" [6], "wicked" [7, 8] and "persistent" [9]. They are characterised by their unstructured, unsolvable nature; containment or management of the problem is the best achievable outcome. Messy problems involve divergent, at times conflicting, interests and perspectives and their urgency prevents comprehensive analysis. Lastly, messy problems involve a tangled web of disparate, interconnected issues: political, social, economic, technological and so on.

The situation in the Middle East is certainly complex when judged by these standards. The notion that urgency prevents comprehensive analysis is demonstrated in the West's dilemma over engagement in Syria. Should the West intervene militarily to stop the bloodshed? Or might such action backfire by strengthening a future Syrian jihadi threat to the West? Better perhaps to err on the side of caution? Or might that lead to increased Iranian influence in the region and thus undermine Western efforts to curb its nuclear aspirations? The unintended consequences of intervention are potentially enormous yet Western decision-makers arguably cannot afford the luxury of waiting, for fear of worsening the conflict.

An illustration of the unsolvable nature of current Middle Eastern conflicts is the Shia-Sunni divide, which is based on opposing views about the prophet Muhammad's succession. Centuries of disagreement, sometimes violent, has led to further entrenchment of positions. Perhaps the epitomy of 
the conflicting interests in the region is the dispute between Jews and Palestinians over the same land, often at each others' expense. The failure of 1993 Oslo Accords to resolve the dispute arguably demonstrates that containment of the problem is the best achievable outcome for the foreseeable future.

The Arab Spring Middle East has added new competing visions of desired futures to the mix. Illustrative are the visions of Syria held by the Assad-regime, the jihadist Jabhat al-Nusra and such activist European states as France and Britain, which range from a caliphate to the restoration of the old order. The many competing visions of desired futures at best only partially reflect present reality. Given the West's uncertain response to the Middle Eastern upheavals, these visions appear to offer insufficient guidance for decision-makers in Western capitals in informing their decisions. These decision-makers might be well served by outlooks that capture a range of possible paths to the future in such a well-reasoned manner that they inform policy. The complexity of Middle Eastern problems and futures research's theoretical basis for tackling complex issues suggests that it might contribute to developing outlooks for the region. The humanitarian disaster surely reinforces the argument that a contribution should be made if possible.

Of the futures research approaches, scenario development is one that might provide a long view since it aims to make sense of messy problems and to explore their future development. Scenario methods' holistic approach and their combination of analytical knowledge and creative thinking could bring a wide range of possible futures together to form manageable outlooks that inform Western decision-making on the Middle East. Moreover, in theory, scenario development "embrace[s] the potential for sharp discontinuities" [10] such as those that occur in the region. Indeed, the scenario community has an interest in addressing the Arab Spring Middle East to offset an over-reliance on last century's best practices as described by Schwartz [11] and Van der Heijden [12] among others. In theory, therefore, scenario development can and should provide a long view for the Middle East. Is current scenario methodology up to the task?

\section{Methodological hurdles}

The complex nature of the Arab Spring Middle East brings certain problems with scenario methodology to the fore. First, scenario development does not explore discontinuity as a matter of course. Second, tension exists within criteria that scenarios must meet to be considered legitimate. Third, the causal reasoning that underpins scenarios cannot sufficiently capture the range of possible future developments. Lastly, there is the challenge of keeping pace with the events on the ground in order to remain relevant.
First, despite the claim that scenario development embraces the notion of discontinuity, research shows that scenarios tend not to stray beyond the beaten path [13]. Discontinuity is difficult to accommodate in scenarios as it requires addressing uncertain and unknowable future issues in present-day frames of reference. Furthermore, the same research shows that 'discontinuity-rich' scenarios are usually products of intuitive, freethinking processes where happy circumstance prompts the consideration of upheavals, rather than any discontinuityoriented methodology. Therefore, it is debateable whether scenario development in itself can adequately explore events and processes as disruptive as those in the Middle East since 2010.

Second, should scenario methodology become more discontinuity-oriented, then certain acknowledged quality standards for scenarios would need to be revised. These include such criteria as internal coherence, consistency, and plausibility [13]. A first problem with the criteria: if the premise is true that scenarios are hypothetical and not predictive, then plausibility surely cannot be expected of them, as they then require premature judgements on the probability of future developments. Furthermore, there is a tension between these criteria and the notion that scenarios stretch the imagination and stimulate 'thinking the unthinkable'. Events sometimes defy explanation in the present and only become coherent, consistent, and plausible in hindsight. Applying the criteria prospectively narrows the spectrum of future possibilities whereby shutting out the unexpected. How would Bouazizi's self-immolation as a trigger for regional upheaval have been judged by these criteria on the eve of the Arab Spring? Probably not very highly. Besides, whether an idea is consistent, coherent or plausible is often subject to interpretation. Thus coherence, consistency, and plausibility are problematic as quality standards for scenarios.

A third handicap is the restrictive nature of the causal reasoning that underlies scenarios. Cause and effect relationships between relevant actors and issues are the cement of scenarios and other futures methodology such as systems analysis and computational models. The afore-named quality standards all reflect the basic requirement that alternative paths to the future are constructed around these relationships. However, the dynamic mesh of causal relationships in the Middle East is arguably too complex to capture in scenarios. Computational models might handle the large number of interactions but such important Middle Eastern issues as religion and ideology are not easily quantified. Participatory scenario processes suffer from the reverse since they are able to tackle qualitative issues yet they lack the capacity for rigorous analysis of large numbers of interactions.

Lastly, the time span of a scenario process for the future of the Middle East is also problematic. Scenario development generally requires a large investment in time and expertise. Consequently, it is usually not a continual process that runs simultaneously to the developments within the subject of 
study. At best, scenarios, once completed, are periodically revised. However, with the Middle East in such flux it is questionable whether scenarios can contribute sufficiently to be meaningful and be timely enough to inform policy decisions, especially given the quality real-time commentary on the Middle East that already exists.

\section{What use for scenarios?}

The methodological hurdles limit the scope for scenario development to inform policy on the Arab Spring Middle East. To become more policy-relevant the notion of discontinuity needs to be embedded in scenario methodology on various levels; epistemological, analytical, contextual, and procedural [13]. On an epistemological level, discontinuity needs to be embraced rather than treated as a novelty or freak accident. On the analytical level, the ambiguous and intangible nature of discontinuity should invite exploration of its various guises rather than being a source of discomfort. On a contextual level, cultures of curiosity to explore discontinuity should be established that are free of political and institutional constraints, yet in close contact with the policy arena. Lastly, on a procedural level, such approaches as chance discovery [14], historical analogy [13], and perspective-based imaging [13] might be used more frequently. Such improvements to scenario methodology are not a tall order. To illustrate, experiments with historical analogy and perspective-based imaging demonstrate that there is promise in these methods [13].

Historical analogy involves the analysis of past situations in the study of the present [15] and helps to inspire thinking about future cases through creative discussions about the future. To illustrate, in an experiment with historical analogy in 2004 parallels were drawn between the 1995 Brent Spar affair and possible disruptions in the then-nascent aquaculture industry [13]. With regards to the contemporary Middle East, an analogy with the 1978 Camp David Accords [16] might help decision-makers in the event of Syria's fragmentation into several separate entities, for example. In 1978, the Sinai desert, originally part of Egypt, had been under Israeli control since its capture in the 19676 Day War. At Camp David, Egyptian and Israeli positions on the future of the Sinai proved incompatible. Israeli security concerns demanded that part of the Sinai remained under Israel's control whereas Egyptian sovereignty claims required the return of the whole territory. A solution was found when Egypt and Israel agreed to a plan that would return the Sinai to complete Egyptian sovereignty and still meet Israeli security concerns by demilitarizing large areas of the peninsula.

Imaging involves the positing of an unlikely event underpinned by a chronology of developments that precede it [17]. The theoretical basis of perspective-based analysis lies in the idea that such factors as norms, values, and experiences influence individuals' views of the world. Perspective-based analysis has been applied in investigations of uncertainty and risk using scenario development [7]. The afore-mentioned 2004 experiment combined imaging and perspective-based analysis and demonstrated its promise for the exploration of potential discontinuity [13]. In the experiment perspectives on the Chernobyl disaster and various food scares were among the cases used to explore possible future disruptions. How a shift in perspectives might provide insights for policy in a Middle Eastern context is illustrated by a 1970 interview with the then Egyptian president Gamal Abdel Nasser [16]. In response to the question what he wanted from his nemesis, Israeli prime minister Golda Meir, Nasser said that she should withdraw from all territory that Israel had captured from Arab forces during the 19676 Day War. When Nasser stated that he was not prepared to offer Meir anything in return, the interviewer asked him what would happen to the Israeli prime minister if she were to concede to his position. "Oh, would she have trouble at home," was Nasser's response. It is suggested that this insight led to a more conciliatory attitude on Nasser's part to negotiating with Israel.

Pending methodological innovation for informing policy, how might scenarios otherwise contribute to a long view for the Middle East? First, tactical scenarios might be developed as used in a military context where so-called war games offer the possibility of simulating potential situations and war rooms offer experts and decision-makers the opportunity to anticipate and respond real time to developments on the ground. These scenarios have a limited scope and can provide timely insights on short-term outcomes of a specific action. They thus offer the possibility for changing tactics as the scenario enfolds. For example, such tactical scenarios might explore possible responses to the kidnap of OPCW weapons inspectors by Syrian opposition forces. Furthermore, it is conceivable that the Obama administration ran through such scenarios with its decision to announce a military response to the chemical attacks on Ghouta, a Damascus suburb, on August 21st, 2013 (though its muddled behaviour afterwards suggests otherwise).

Second, scenario development might also contribute as educational and awareness-raising aids for students and observers of the Middle East. Time is less of a constraint when used for educational purposes and it allows for a more open exploration of issues than with the more narrow goal of informing to policy decisions. Furthermore, a more thorough investigation is possible and participatory methods such as stakeholder-workshops, focus groups and policy exercises might be part of such a scenario process [7].

\section{Conclusion}

The upheavals in the Middle East cry out for a long view yet scenario methodology appears limited in what 
it can offer Western decision-makers. Tactical and educational scenarios are feasible but a meaningful policy informing role is hampered by a several methodological problems. In order to become more policy relevant, methodological innovation is particularly needed in the integration of the notion of discontinuity in scenario development. Previous experiments have provided encouraging results. The Middle East is likely to remain in flux for some time. There is still ample opportunity for a contribution from the scenario community to a Middle Eastern future after the Arab Spring.

Acknowledgments The author would like to thank the many people who have contributed to this paper by sharing their insights over the years. Special thanks goes to Robert Bood whose critical and nonconformist thinking has provided much inspiration.

Open Access This article is distributed under the terms of the Creative Commons Attribution License which permits any use, distribution, and reproduction in any medium, provided the original author(s) and the source are credited.

\section{References}

1. Heart and soul: Heirs of the Prophet, BBC World Service, 18 June 2013

2. Iraq body count. http://www.iraqbodycount.org. Accessed 25 September 2013
3. Displacement: The New 21st Century Challenge, UNHCR Global Trends 2012. http://www.unhcr.org/statistics. Accessed 18 June 2013

4. Security Council SC/11063 (2013) Humanitarian chief warns of 'unfolding tragedy' in Syria. http://www.un.org/News/Press/docs/ 2013/sc11063.doc.html. Accessed 16 July 2013

5. Letter to the Editor, The national, 21 September 2013: 12

6. Vennix J (1996) Group model building: Facilitating team learning using system dynamics. Wiley, Chichester

7. Van Asselt MBA (2000) Perspectives on uncertainty and risk: The PRIMA approach to decision support. Kluwer, Dordrecht

8. Bovens M, 't Hart P (1996) Understanding policy fiascoes. Transaction Publishers, New Brunswick

9. Rotmans J (2003) Transitiemanagement: Sleutel voor een duurzame samenleving (Transition management: Key to sustainable society). Van Gorcum, Assen

10. Berkhout F, Hertin J, Jordan A (1998) Socio-economic futures in climate change impact assessment: using scenarios as 'learning machines'. Science and technology policy research. University of Sussex, Brighton

11. Schwartz $P$ (1996) The art of the long view: Planning for the future in an uncertain world. Currency Doubleday, New York

12. Van der Heijden K (1996) Scenarios: The art of strategic conversation. Wiley, Chichester

13. Van Notten PWF (2005) Writing on the wall: Scenario development in times of discontinuity. Dissertation.com, Boca Raton

14. McBurney, P. and Parsons, S., (2003) Chance discovery and scenario analysis. New generation computing, special issue on Chance Discovery 21:13-22

15. Neustadt RE, May ER (1988) Thinking in time: The uses of history for decision makers. The Free Press, New York

16. Fischer R, Ury W (2012) Getting to yes: Negotiating an agreement without giving in. Random House, London

17. Kates RW, Clark W (1996) Environmental surprise: expecting the unexpected. Environment 2:6-11 